\title{
THE REGULATION OF CONSUMER CREDIT INSURANCE
}

\author{
Fredertck G. Davis, Wayne E. Etter, Harry Blythe, and Peter F. Freund*
}

\section{Introduction to Consumer Credit Insurance}

Consumer credit insurance may be classified under two broad headings: credit life insurance and credit accident and health insurance. Credit life insurance generally provides a death benefit large enough to repay the creditor the outstanding balance of the indebtedness at the time of the debtor's death. Credit accident and health insurance guarantees that the debtor's periodic payments will be met if he is incapacitated because of injury or illness.

Both types of insurance may be used only in connection with credit extensions which are repayable within a specified number of years. Insurance is ordinarily obtained by the borrower at the point where the credit transaction takes place-that is, from a financial institution or a vendor. The borrower may be covered under a group policy or by an individual contract, and, in either case, the creditor is the primary beneficiary of the insurance.

\section{A. Origin and Development}

Consumer credit insurance in the United States is an outgrowth of the credit life insurance policies first written in 1917 by the Morris Plan Insurance Society, which was established by Arthur J. Morris, founder of the "Morris Plan" banks or companies. Each individual policy was written in an amount sufficient to pay the loan should the borrower die before repayment was made. From this beginning evolved the basic principle of consumer credit insurance that a man's debts ought not to outlive him.

Since 1945 , the increase in consumer credit insurance in force has roughly paralleled the increase in the dollar volume of consumer indebtedness. With the rapid growth in recent times in the use of credit by consumers, especially in the various types of

\footnotetext{
* The authors are all members of an Ohio University research team which is conducting a comprehensive study of the consumer credit insurance industry. The subject matter contained in the paper is based on interim findings. The completed study will be published in late 1969 .

Frederick G. Davis: B.S., University of Illinois; M.S., San Jose State College; Ph.D., Michigan State University. Assistant Professor of Accounting, Ohio University. Certified Public Accountant, California. Wayne E. Etter: B.B.A., M.B.A., Ph.D., The University of Texas. Assistant Professor of Finance, Ohio University.

Harry Blythe: B.S., M.S., Columbia University. Professor and Chairman, Department of Finance, Ohio University. Director of the Consumer Credit Insurance Study at Ohio University.

Peter F. Freund: B.B.A., City University of New York; M.A., Ph.D., New York University. Associate Professor of Finance, Ohio University. Formerly Director of the Consumer Credit Insurance Study at Ohio University.
} 
installment financing, consumer credit insurance has become the fastest growing segment of the insurance industry. Approximately $\$ 67$ billion of credit life insurance was in force at the end of 1967 , compared with less than a half billion dollars in $1945^{1}$ This increase in the volume of credit life insurance has been accompanied by a corresponding increase in the percentage of consumer indebtedness covered by insurance. In I945, approximately seven per cent of total consumer borrowing was protected by credit life insurance; in 1967 this figure had risen to about sixty-seven per cent. ${ }^{2}$ Although comparable data for credit accident and health insurance are not available, the outstanding volume and penetration of this type of credit insurance is much lower than that of credit life insurance. However, data on premium volume indicate that credit accident and health insurance has grown more rapidly than credit life insurance in recent years. ${ }^{3}$

\section{B. Characteristics of Credit Life Insurance}

Most credit life insurance in force is decreasing-term life insurance sold at a flat premium rate on a group basis with a minimum of underwriting limitations. Although credit life insurance may be obtained on a group or individual basis, group insurance is far more prevalent. About eighty-six per cent of the credit life insurance in force at year-end 1967 was group insurance. ${ }^{4}$

Group insurance is issued to the creditor by the insurance company; the creditor becomes the policyholder and enrolls the debtor. The borrower receives a certificate which describes his insurance coverage. Since the insurance company does not select the applicants and a medical examination is not ordinarily required, the availability of insurance is determined by the creditor agreeing to grant credit. A majority of the insurance companies impose underwriting limitations with respect to the amount of coverage and the maximum age. Additional limitations may be imposed in the application for insurance or may be imposed under the laws of the various states.

When credit life insurance is obtained under an individual policy, the borrower is issued a policy by an agent of the insurance company. The insurance company generally relies on an employee of the creditor acting as agent to sell this type of insurance. Since both types of insurance are marketed through the same channels using similar mass handling techniques, the risk exposure of the insurer is the same.

Credit life insurance is ordinarily of the decreasing-term type since it is almost

\footnotetext{
${ }^{1}$ Institute of Life Insurance, Life Insurance Fact Book 33 (I968) [hereinafter cited as I968 LIFE INSURANCE Fact BOOK].

2 The percentage of coverage is calculated from data on consumer credit outstanding in 54 Fed. REs. Bull., No. II, at A-52 (I968), and from data on credit life insurance in force in $x 968$ LIFE INSURANCE FAcr Book, supra note 1 . The percentage of outstanding consumer credit that is insured is somewhat overstated because the credit life insurance total includes an unspecified amount of mortgage protection insurance issued through lenders plus an unspecified amount of protection on agricultural loans.

${ }^{3}$ See, The Spectator, October issue for various years.

- 1968 Life Insurance Fact Book.
} 
always issued in connection with installment debt contracts. As the debt is reduced through the payment of periodic installments, the amount of insurance coverage is reduced concurrently. In this way, the amount of insurance remains approximately equal to the scheduled amount of the unpaid indebtedness. Level-term credit insurance is used in connection with single-payment loans to provide full insurance coverage during the life of the loan.

The premiums paid for credit life insurance are not usually based on the age distribution of the insured debtors. Instead, a flat premium rate applicable to all borrowers of any one creditor is ordinarily used. The cost of credit life insurance is borne by the debtor; the charge may be separately identified, or it may be included as part of the total financing charges. In either case, the creditor remits the premiums to the insurer.

\section{Characteristics of Credit Accident and Health Insurance}

Credit accident and health insurance in most respects resembles credit life insurance. Credit accident and health insurance, like credit life insurance, may be obtained on a group or individual basis. It is sold through the same institutions, using the same techniques; the premiums are remitted to the insurer by the creditor; and the borrower generally pays the cost of the insurance.

There are differences, of course. If the borrower becomes disabled, the monthly installments are paid by the insurer only for the duration of the disability or until the maturity date of the loan, whichever occurs first. In addition, underwriting conditions are necessarily stricter than in the writing of credit life insurance. Normally a maximum is placed on the amount of the periodic payments made on each insured credit transaction by the insurer to the creditor beneficiary. If the borrower had been disabled within some specified period prior to becoming insured, benefits are ordinarily not payable if the condition recurs. The borrower may be required to be gainfully employed in order to secure insurance.

Credit accident and health benefits are not payable unless the insured debtor remains continuously disabled for a specified waiting period as defined in the policy. If the disability ceases prior to the expiration of the waiting period, no benefits are paid. Benefits may either be retroactive or nonretroactive. If they are retroactive, benefits will be paid from the first day of the disability, provided the period of the disability exceeds the waiting period. If benefits are nonretroactive, they will be paid only for the period of disability beginning with the end of the waiting period.

The differences between credit life and credit accident and health insurance result from the disparities in the degree of exposure assumed by the insurer-the risk of death versus the greater risk of accident or illness. Consequently, the problems of rate setting, administration, and regulation in credit accident and health insurance are even more complicated than they are for credit life insurance. 
II

\section{Public Concern and Regulation}

During the years of rapid growth in consumer credit insurance, there also developed public concern about some industry practices which were thought to be unfair and, in a few instances, abusive. This concern was publicly acknowledged in I948 when the National Association of Insurance Commissioners (the NAIC) appointed a subcommittee for credit life and accident and health insurance..$^{5}$ The practices which attracted attention at that time included excessive insurance, pyramiding of insurance coverages, overcharging, coercion, and nonpayment of claims. ${ }^{\circ}$ After studying the problems then afflicting the industry, the first draft of the NAIC Uniform Consumer Credit Insurance Rules and Regulations (the "Rules and Regulations") was submitted in $1952 .{ }^{7}$ These rules were adopted by the NAIC in June, $1954^{8}$

Public concern was further indicated in 1954 when the Subcommittee on Antitrust and Monopoly of the Senate Judiciary Committee investigated the tie-in sale of consumer credit insurance in the small-loan industry. ${ }^{9}$ The interest of the subcommittee was particularly noteworthy since Congress had nine years earlier passed the McCarran Act, which exempted insurance from antitrust legislation and allowed the states to continue regulating insurance but which at the same time made it clear that Congress would examine state statutes in order to determine the effectiveness of state regulation. ${ }^{10}$

Although the NAIC Rules and Regulations, if properly enforced, could have corrected the abuses practiced at that time, they were not widely adopted by the states because they did not provide insurance commissioners with the power to regulate premium rates. Ultimately, the Rules and Regulations did serve as the foundation for the formulation of the NAIC's Model Bill for the Regulation of Credit Life and Credit Accident and Health Insurance (the "Model Bill") adopted in December 1957. As enacted in the various states, the Model Bill was the first major reform in consumer credit insurance. It differed from the Rules and Regulations in that it gave to the state insurance commissioner a full statutory authority to regulate

\footnotetext{
'Address of NAIC President J. Edwin Larson, National Association of Insurance Commissioners, I949 Proceedings 19-20 [hereinafter cited as NAIC 19- Proceedings].

${ }^{\circ}$ Larson, Problems of State Regulation, 413 Ins. L.J. 327 (1957).

${ }^{7}$ Proposed Rules and Regulations Governing the Sale of Credit Life and Credit Accident and Health Insurance, NAIC 1952 PROCEEDINGS 766-73.

${ }^{8}$ Report of the Credit Life and Credit Accident and Health Subcommittees, 2 NAIC 1954 ProCEEDINGS 299-309, 335 .

- Subcomin. on antitrust and Monopoly of the Senate Conm. on the Judiclary, 83d Cong., 2D Sess., Report on the Tie-in Sale of Credit Insurance in Connection with SMall Loans and Other Transactions (Comm. Print I955).

${ }^{10}{ }_{5}$ U.S.C. $\$ \S$ IOII-I3 (I964).

${ }^{11}$ Report of the Committee on Insurance Covering All Installment Sales and Loans, I NAIC x958 Proceedings ro4. The current version of the Model Bill, revised December I960, appears in I NAIC I96I Proceedings 300 [hereinafter cited as Model Bill].
} 
consumer credit insurance, including the power to "disapprove any [policy] form if the benefits provided therein are not reasonable in relation to the premium charge."12

\section{III}

\section{Statutory Regorms: A Comparison}

Corrective legislation has evolved or is evolving to control the principal abusive practices which were and are of concern in the consumer credit insurance industry. This legislation is a combination of (a) existing state laws, for the most part based on the NAIC Model Bill, $(b)$ the recently enacted, but not yet effective, federal Consumer Credit Protection Act (the "CCPA"), and (c) the recently promulgated Uniform Consumer Credit Code (the "UCCC"), which is just coming before state legislatures.

There is ample justification for considering the NAIC Model Bill as the standard of existing state legislation. Thirty-one states, the District of Columbia, and Puerto Rico have enacted it in substantially the form recommended by the NAIC. ${ }^{13}$ Furthermore, the insurance commissioners of six additional states have promulgated regulations patterned substantially after the Rules and Regulations adopted by the NAIC in 1954, which became the basis for the Model Bill. ${ }^{14}$ Three additional states have statutes which, by vesting broad regulatory authority in the insurance commissioner, are tantamount to the Model Bill provisions. ${ }^{15}$ The remaining ten states have only limited consumer credit insurance regulation; in three of these states, either the maximum allowable premium rate is set by statutes governing small loans or the authority to set the rate is granted by lending laws. ${ }^{18}$ Because the majority of the states have enacted legislation or adopted regulations similar to the NAIC Model Bill, to date it represents the major reform actually put into practice in the field of consumer credit insurance.

The CCPA, passed by the Congress in May $x 968$ and signed into law by the President on May 29, $1968,{ }^{17}$ is the culmination of what began as a "Truth-in-Lending" bill in I960. The CCPA is divided into four titles. Title I deals with consumer credit cost disclosures and has been given the short title of the "Truth in Lending Act." Chapters 2 and 3 of Title I pertain to the disclosure of credit insurance premiums and will be discussed below with the disclosure requirements of the UCCC and the NAIC

\footnotetext{
${ }^{19}$ Report of Committee on Instrance Covering All Installment Sales and Loans, I NAIC 1958 ProCEEDINGS IO4, IIO.

${ }^{18}$ The thirty-one states are Alaska, Arizona, Arkansas, California, Connecticut, Delaware, Florida, Georgia, Idaho, Illinois, Indiana, Maine, Michigan, Minnesota, Montana, Nebraska, Nevada, New Hampshire, New Jersey, New Mexico, Ohio, Oregon, Pennsylvania, Rhode Island, South Dakota, Texas, Utah, Vermont, Virginia (excludes $\$ 7 . \mathrm{B}$ ), Washington, and Wyoming.

${ }^{14}$ The six states involved are Alabama, Iowa, Kansas, Kentucky, North Carolina, and Tennessec.

${ }^{10}$ These states are New York, West Virginia, and Wisconsin.

${ }^{16}$ The maximum permissible rate is set by a small loan statute in Massachusetts, while in Louisiana and Mississippi authority to establish a maximum rate is granted regulatory officials by lending laws. ${ }^{17} 82$ Stat. I46 (I968) [hereinafter cited as CCPA].
} 
Model Bill. The other titles of the CCPA deal with "extortionate credit transactions" (i.e., loan sharking), wage garnishments, and the creation of a National Commission on Consumer Finance.

The UCCC was promulgated at the rg68 annual meeting of the National Conference of Commissioners on Uniform State Laws. It was prompted by the recognition of the unfortunate state of consumer credit regulation, which featured wide variations among the states and seriously inconsistent and unintegrated legislation within each state. Meeting the rapid growth of consumer financing with only piecemeal legislation, the states had produced a regulatory framework that differed for each type of creditor and often even for different types of goods and services procured on credit. The resulting chaos prompted a threat of federal legislationand ultimately enactment of the CCPA-and this threat also generated the effort to develop the UCCC.

The UCCC's main reliance is not on more regulation but on improving competition as a means of providing increased consumer protection. By requiring uniform disclosure, which would permit credit users to shop more effectively for terms, and by promoting greater freedom of entry into the consumer finance industry, the UCCC embodies the preference for a more competitive economic market for consumer installment credit. The preference for disclosure as a stimulus to competition is reflected in the Code's article 4 governing consumer credit insurance, but additional regulatory steps are also taken in this area. This section of the paper is devoted to showing how the UCCC and the disclosure provisions of the CCPA are related to the NAIC Model Bill. The final section of the paper examines the controversy surrounding premium rate regulation, a matter that is not resolved by any of the three acts.

\section{A. Basic Coverage}

Although there are many similar provisions, the UCCC and the NAIC Model Bill do not overlap because, by the Code's express declaration, they are henceforth to be regarded as directed toward different parties in the consumer credit insurance transaction.' The Code sets forth the relationship as follows:

This Article supplements and does not repeal the Credit Insurance Act [the Model Bill]. The provisions of this Act concerning administrative controls, liabilities, and penalties do not apply to persons acting as insurers, and the similar provisions of the Credit Insurance Act do not apply to creditors and debtors. ${ }^{18}$

This provision of the Code is more than merely descriptive. It is ipso facto a change in the Model Bill's coverage. Its effect is to nullify those provisions of the Model Bill that expressly apply to creditors and to make the Code's provisions the exclusive rule as to creditors' practices with regard to credit insurance. This legislative legerdemain

\footnotetext{
${ }^{18}$ UNIForM Consumer CREDIT CODE $\$ 4.102(3)$ [hereinafter cited as UCCC]. On the text of the UCCC, see Foreword, in this symposium, p. 639 n.I.
} 
serves the intended useful purpose of collecting the law of consumer credit in one place but has also the perverse effect of altering the clear sense of existing legislation without formally amending it. ${ }^{19}$ This circumstance seems to have no major substantive significance, however, as the UCCC incorporates all of the Model Bill's provisions formerly governing creditors' practices. ${ }^{20}$ In addition, the UCCC goes beyond the Model Bill and contains special provisions for the regulation of consumer credit insurance on revolving credit sales accounts and revolving credit loans. ${ }^{21}$ These are relatively new forms of consumer credit, and the drafting of the UCCC presented an opportunity to consider insurance problems connected with the newer types of consumer credit transactions.

Due to the many similar provisions in the NAIC Model Bill and the UCCC, the state consumer credit administrator, to be created under the UCCC, will have to be careful not to infringe on the responsibilities of the commissioner of insurance. The UCCC calls upon the administrator and the commissioner of insurance to consult and assist one another in assuring compliance with the insurance provisions. Further, the UCCC states that joint investigations, suits, and other official actions may be taken and that the administrator is to notify the commissioner of insurance of any violation or suspected violation by an insurer. ${ }^{22}$

The coverage of the CCPA would detract from the UCCC's claim to exclusivity if it were not for the provision in the former that would exempt transactions in any state in which local legislation imposing requirements "substantially similar" to the CCPA is in effect. ${ }^{23}$ The UCCC is expected to qualify under this provision and to emerge as the exclusive legal protection for users of consumer credit. In states where the UCCC is not enacted, the Model Bill and the CCPA may each govern, each imposing certain duties on creditors. There appear to be no inconsistencies, however.

\section{B. Amount of Consumer Credit Insurance ${ }^{24}$}

One of the persistent problems in consumer credit insurance has concerned the sale of insurance in amounts in excess of the indebtedness involved. The initial

\footnotetext{
${ }^{10}$ In this way, the following sections of the Model Bill are rendered nugatory: $\$ 8 \mathrm{~B}$ (requiring refunds of premiums upon prepayment; compare UCCC $\$ 4.108$ ); $\$ 8 \mathrm{C}$ (requiring written notice by the creditor to the debtor in certain circumstances; compare UCCC $\$ 4.105(2)$ ); $\$ 8 D$ (limiting the creditor's charge to the debtor to the amount of the premium actually paid; compare UCCC $\$ 4.107)$; $\$$ II (requiring the creditor to give the debtor the option of obtaining insurance from another source; compare UCCC \$4.109). The Model Bill provided no powers of administrative enforcement against creditors (see $\S \mathrm{I} 2$ ), but debtors might have had the benefit of implied rights under the foregoing provisions. Under the UCCC their sole remedies will be under the Code.

${ }^{20}$ See note 19 supra, in which the comparable UCCC provisions are noted. The UCCC provisions do not, however, track the Model Bill verbatim.

${ }^{21}$ UCCC $\$ \S 4.107(2), .201(2)(2), .202(2)$.

${ }^{22}$ UCCC $\$ 4 . I I I$.

${ }^{23}$ CCPA $\$ 123$.

24 It should be noted that the questionable practices described should not be construed as representative of all insurers and creditors involved in offering consumer credit insurance. The vast majority of reputable insurers and creditors abhor such practices and actively encourage the drafting and enactment of such legislation as the Model Bill and the UCCC.
} 
amount of credit life insurance under both the UCCC (except for revolving credit and revolving loan accounts) and the Model Bill is limited to the amount of the indebtedness, and, if the debt is repayable in installments, the insurance may not exceed the greater of the scheduled or actual amount of the unpaid debt. ${ }^{25}$ The total amount of benefits payable for accident and health insurance is limited to the total of scheduled unpaid installments of the indebtedness, and the amount of each periodic benefit is limited to the original indebtedness divided by the number of periodic installments. ${ }^{26}$ The UCCC goes further than the Model Bill by specifically including maximum benefit provisions for consumer credit insurance provided in connection with a revolving charge account or revolving loan account. ${ }^{27}$

\section{Term of Consumer Credit Insurance}

Another reform has concerned the writing of insurance for a term in excess of the scheduled period of indebtedness. Under ordinary circumstances, both the UCCC and the Model Bill provide that the commencement date of the insurance is to be the day the indebtedness is incurred. Each sets the maximum term of the insurance as not more than fifteen days after the originally scheduled due date of the last scheduled payment of the debt, unless it is extended without additional cost to the debtor. ${ }^{28}$ The UCCC adds that the insurance may be extended as an incident to a deferral, refinancing, or consolidation; in these circumstances the Model Bill appears to contemplate termination, refund, and new insurance rather than an extension, a seemingly insubstantial difference. ${ }^{29}$

\section{Fair Disclosure and Evidence of Insurance}

Both the UCCC and the CCPA have as a fundamental purpose the disclosure to credit users of information necessary to making decisions concerning credit terms and to shopping for better terms with other lenders. In pursuance of this objective, both would require disclosure of the amount of the insurance premium and the details as to coverage prior to the extension of credit. These requirements have no analogue in the provisions of the NAIC Model Bill. Nevertheless, additional disclosure problems appear to exist, and they are dealt with in the provisions of both

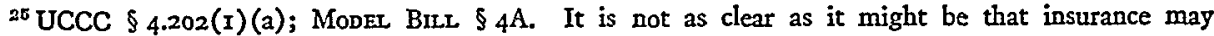
cover accrued interest and associated insurance and other finance charges.

${ }^{20}$ UCCC $\S 4.202(\mathrm{I})(\mathrm{b})$; MODEL BILI $\S 4 \mathrm{~B}$.

37 The maximum benefits from consumer credit insurance that may be provided in connection with revolving charge or loan accounts are limited to those which "may be reasonably commensurate with the amount of debt as it exists from time to time." UCCC $\$ 4.202(2)$. See Buerger, Revolving Credit and Credit Cards, in this symposium, p. 707, 7x5.

${ }^{28}$ Model BiLl $\S 5$; UCCC $\$ 4.20 \mathrm{r}(3)$. The UCCC also contains a special provision limiting the term on revolving charge or loan accounts by stating that the term "need extend only until the payment of debt under the account and may be sooner terminated after at least 30 days' notice to the debtor." UCCC $\$ 4.201(2)(6)$.

${ }^{30}$ UCCC $\S 4.110 ;$ MODEL BILI $\S 5$.
} 
the UCCC and the Model Bill. The two types of disclosure problems are discussed separately.

\section{x. Disclosure Prior to the Extension of Credit}

In pursuance of the objective of improving the information available to credit users in the making of their credit decisions, the UCCC and the CCPA require disclosure of the terms of credit insurance. In some circumstances, however, the charge for consumer credit insurance is required to be included in the total finance charge, which includes interest and other items which the creditor may attempt to tack onto the credit obligation. The question that arises is this: When may the premium for consumer credit insurance be treated as a separate charge and not included in the finance charge?

The conditions that must be satisfied to allow charging a separate premium are substantially identical under the UCCC and the CCPA. The UCCC states them as follows:

An additional charge may be made for [consumer credit] insurance . . . if the insurance coverage is not a factor in the approval by the seller of the extension of credit and this fact is clearly disclosed in writing to the buyer and if, in order to obtain the insurance in connection with the extension of credit, the buyer gives specific affirmative written indication of his desire to do so after written disclosure to him of the cost thereof. .30

When these conditions are not met, the UCCC and the CCPA would both require the inclusion of the insurance premium in the finance charge for purposes of disclosure. The UCCC requires in addition that the insurance charge be included in the finance charge for the purposes of determining compliance with the ceiling rates on finance charges established in the Code. ${ }^{31}$ Thus, if the creditor requires life insurance in connection with the loan or credit sale, the creditor will be unable to make a separate charge for insurance under the CCPA. Under the UCCC, he would find himself subject to the Code's restrictions on "supervised loans" if the finance charge (including the insurance charge) exceeds an annual rate of eighteen per cent, and the Code's absolute rate ceilings for supervised loans would also apply.

\section{Disclosure Following the Extension of Credit}

Considerable injustice is alleged to have occurred where neither the debtor nor his next-of-kin were aware of the existence of consumer credit insurance, or where, if they had knowledge of insurance, they were not fully cognizant of the extent and the details of coverage. Reforms embodied in the NAIC Model Bill, and subsequently in the UCCC, require the delivery to the debtor of the individual policy or, in the case of group insurance, a certificate of insurance within thirty days after the

\footnotetext{
${ }^{30}$ UCCC $\$ \$ 2.202(2)$; the parallel provision in the article on loans is UCCC $\$ 3.202(2)$; compare CCPA $\S$ ro6(b).

${ }^{31}$ UCCC $\$ 2.202(2)$, Comment.
} 
term of insurance commences. ${ }^{32}$ The CCPA has no analogous provision, but the disclosure required prior to the extension of credit would, of course, serve the purpose of better informing debtors of the amount and extent of their insurance coverage.

The Model Bill appears to give more attention to the problem of disclosure of terms and limitations of the insurance than does the UCCC. The UCCC simply requires the delivery of an individual policy or certificate of insurance to the debtor within thirty days after the term of the insurance commences. While the content of the certificate of insurance is not specified in the Code, it is clear that the provision has reference to the Model Bill's requirement that the insurer deliver such a certificate, the substance of which is spelled out at length, or the individual policy to the debtor within thirty days after the indebtedness is incurred. Thus the insurer's delivery of the policy or a certificate would meet the creditor's obligation under the UCCC, and the UCCC merely adds a requirement that the creditor is responsible for the certificate's or policy's delivery and must make sure that the insurer complies with his obligations under the Model Bill. In a state where the Model Bill is not in effect, the content of the certificate of insurance required by the Code would not be clear or could be ascertained only by reference to other state law.

\section{E. Choice of Insurer}

The nature of the marketing transaction involving consumer credit insurance provides the creditor with an opportunity to compel the consumer to purchase the insurance. To prevent the creditor from forcing the insurance upon the debtor, the NAIC Model Bill provides that the debtor, if required by the creditor to show evidence of insurance, has the option of furnishing it through an existing policy or through a policy purchased elsewhere. ${ }^{33}$ The UCCC contains a similar provision but adds a clause stating that the creditor may for reasonable cause decline the insurance secured by the debtor; ${ }^{34}$ as noted earlier, the UCCC would supersede the Model Bill insofar as creditors are concerned.

\section{F. Premiums and Refunds}

Consumer credit insurance is marketed by financial institutions or vendors as a transaction incidental to the main transaction of providing cash loans or sales credit to finance the purchase of consumer goods or services. The insurance company has little direct contact with the consumer and relies upon the creditor for most data pertaining to the insurance transaction. The creditor is usually compensated by the insurance company for providing the insurance to the debtors. Allegations were made that in some instances creditors charged debtors higher premium rates than

\footnotetext{
${ }^{83}$ UCCC $\$$ 4.I05; MODEL BILL $\$ 6$.

${ }^{8 B}$ Model BILI $\$$ II.

s4 UCCC $\$ 4.109$.
} 
the rates for consumer credit insurance charged by insurance companies to creditors. Further, when the indebtedness was liquidated prior to the scheduled maturity date and the insurance was terminated, the debtor, in some instances, did not receive a refund or credit from the creditor.

Reforms contained in the NAIC Model Bill provide that the amount charged the debtor for insurance may not exceed the premiums charged the creditor by the insurer, computed at the time the charge to the debtor is made, and must conform to the rate filed with the insurance department. ${ }^{35}$ The UCCC contains a similar provision and further specifies procedures for calculating the premium to be charged the debtor on revolving charge accounts and revolving loan accounts. ${ }^{36}$ As noted earlier, the UCCC provision would supersede the Model Bill's apparent coverage of creditor practices.

The failure to file for refunds of unearned insurance premiums is covered by the UCCC. Section 4.108 requires the creditor promptly to refund or credit to the debtor any "unearned premium" when a loan or credit sale is prepaid or the insurance is provided for a shorter term than originally computed. The Model Bill contains similar refund requirements but does not specifically state who is responsible for making the refund. ${ }^{37}$ Again, enactment of the UCCC would preclude application of this requirement to creditors, but in the absence of the Code debtors would still appear to have a claim to such a refund by the creditor.

The UCCC goes beyond the refund provisions of the Model Bill in specifying that appropriate refunds are to be made when an insured credit sale or loan is prepaid by the proceeds of credit insurance. ${ }^{38}$ Normally, no premium refund would be appropriate under these circumstances. However, the UCCC section states,

Upon prepayment in full of a consumer credit sale or consumer loan by the proceeds of consumer credit insurance, the debtor or his estate is entitled to a refund of any portion of a separate charge for insurance which by reason of prepayment is retained by the creditor or returned to him by the insurer ....

Such a refund requirement could arise in the following circumstance: The creditor charges the debtor the total premium at the time the indebtedness is incurred but remits only a portion of the premium periodically to the insurer; the debtor then dies and the indebtedness is prepaid by the proceeds of the insurance before the creditor has remitted the total premium to the insurer.

\section{G. Creditor Compensation}

It is common industry practice for the insurer to compensate the creditor for marketing and handling consumer credit insurance. The creditor is generally allowed

\footnotetext{
${ }^{35}$ MODEE. BILI $\$ \$ 8 \mathrm{~A}, \mathrm{D}$.

${ }^{80}$ UCCC $\$ 4.107$.

${ }^{37}$ Modez BurL \$\$ 8B, C.

${ }^{33}$ UCCC $\$ 4.108(\mathrm{I})$.
} 
to retain as a commission a percentage of the premiums collected or is granted a retrospective rate credit or dividend based on its own favorable mortality or morbidity experience. It is clear that neither the Model Bill nor the UCCC regard such commissions or experience credits or dividends as premium refunds which are required to be returned to debtors. The Model Bill does not contain any reference to such creditor compensation by the insurer. A proposal for the inclusion of restrictions on creditor compensation was rejected by the NAIC in I959. Its rejection was attributed to a combination of two factors: first, difficulties in explaining to insurance commissioners how a percentage limitation on creditor compensation could be enforced, and second, opposition from representatives of creditors, who felt that a limitation of compensation to forty per cent of premiums, the percentage which had gained the greatest support, was too low. ${ }^{39}$

Following the defeat of the proposal, certain state insurance departments began adopting their own regulations governing creditor compensation. The first state to do so was Nebraska, whose Director of Insurance issued a bulletin which read as follows:

The Department will approve no rates or policy forms wherein retrospective rate credits or retrospective commissions are to be paid to lenders based upon favorable loss experience which can exceed a total commission substantially in excess of $30 \%$. Violation of the terms of this letter by admitted companies may be grounds for immediate disapproval of all credit policy forms and rate schedules by this department, or for action against the company license itself.40

Recently, the Director of Insurance of Illinois, in an effort to attain a reasonable relationship between the benefits of consumer credit insurance and its cost, a matter to be discussed in a subsequent section of this paper, issued a bulletin and accompanying letter in which he stated that commissions or compensation payments greater than forty per cent are excessive and would be deemed a prima facie violation of the fifty per cent loss ratio, a standard which requires a return to the debtor public of at least fifty per cent of their premiums in the form of benefits. His rationale for issuing the bulletin is that compensation in excess of forty per cent cannot contemplate a loss ratio of fifty per cent or more since administrative costs and other expenses must also be met. ${ }^{41}$ As of November 1968, eleven state insurance departments have established some form of limitation on the amount of compensation payable to creditors in connection with the sale of consumer credit life and accident and health insurance. $^{42}$

\footnotetext{
${ }^{30}$ Doss, Rate Regulation in Consumer Credit Insurance, 528 INs. L.J. r9 (1967).

${ }^{10}$ Nebraska Bulletin, dated January 15, I960, from William E. Grubbs, Director of Insurance, to all insurers writing consumer credit insurance in the state.

${ }^{11}$ Illinois Bulletin, dated October 15, 1968, from John F. Bolton, Jr., Director of Insurance, to all companies issuing credit life insurance or credit accident and health insurance.

${ }^{6}$ The states and percentage of creditor compensation permitted are Arizona (371/2\%), Arkansas (35\%), Illinois (40\%), Indiana (40\%), Michigan (40\%), Nebraska (33 $13 \%$ ), Nevada ( $40 \%)$, Ohio $(35 \%)$, Tennessee $(40 \%)$, Texas $(35 \%)$, and Washington $(40 \%)$.
} 
While the Model Bill omits to deal with creditor compensation, the UCCC contains a provision relating to the subject in section 4.108(2)(c), which pertains to dividends. This provision states that the creditor is not required to account to the debtor for any "gain or advantage not prohibited by law" which the creditor may derive from the sale of such insurance. The official comment relating to this provision of the UCCC defends this position as follows: ${ }^{43}$

Subsection (2)(c) of Section 4.108 permits a creditor to derive from consumer credit insurance gains and advantages such as dividends and refunds resulting from favorable mortality or morbidity experience with respect to insured debtors.

The provisions of Article 4 relating to consumer credit insurance are predicated on the Special Committee's conclusions that:

I. Although the gains and advantages may be large to the creditor, they are relatively insignificant to each insured debtor and the calculating, clerical and mailing costs of returning them to insured debtors would be unreasonably disproportionate to the amounts involved.

2. The requirements of Article 4 that premiums for consumer credit insurance be reasonable in relation to benefits, if properly enforced by the State insurance commissioner or superintendent, will preclude the possibility of the use of consumer credit insurance as a device by creditors for concealing hidden charges from debtors.

The UCCC thus permits the current practice of not passing on experience refunds to the debtor. In addition, the UCCC sanctions creditor compensation by the insurer and denies the debtor any refund because of creditor compensation. It nevertheless suggests that the problem is a proper one for the attention of those responsible for the regulation of insurance rates. The problem thus merges with those discussed in the final portion of this paper.

\section{H. Deferrals, Refinancing, or Consolidation}

The practice of issuing a new policy to cover an indebtedness which has been refinanced without cancelling the existing policy and refunding the unearned premium is called pyramiding. The motive for pyramiding is apparent when it is noted that the creditor receives compensation representing a portion of the premium on every sale of consumer credit insurance. The NAIC Model Bill provides that if an indebtedness is discharged by renewal or refinancing prior to maturity, any insurance in force must be cancelled prior to issuing new insurance. Any unearned premium on the cancelled insurance is to be refunded. ${ }^{44}$

Under the provisions of the UCCC, the creditor may not make a separate charge for new insurance in connection with a deferral, a refinancing, or a consolidation unless all of the following conditions exist:

(a) the debtor agrees that the charge may be made;

\footnotetext{
${ }^{13}$ UCCC $\$ 4.108$, Comment.

${ }^{14}$ MODEI BILI $\$ 5$.
} 
(b) the debtor's insurance protection is increased in amount, term or kind over the insurance provided under the original indebtedness;

(c) the debtor receives a proper refund of the unearned premium on the cancelled insurance; and

(d) the premium charge does not exceed the amount permitted elsewhere in the Code. $^{45}$

\section{IV}

\section{Premium Rate Regulation}

Most of the recognized abusive practices in the consumer credit insurance industry can be dealt with effectively if the NAIC Model Bill and the UCCC are adopted and enforced. There is some reason to believe that such practices have been largely eliminated in those states that have adopted the Model Bill, and enactment of the UCCC would provide important remedies to debtors and, more importantly, effective enforcement against creditors who continue to abuse credit insurance. A review of consumer insurance hearings before state insurance regulatory authorities indicates that the major efforts of the industry and the regulatory agencies are now primarily directed toward resolving the issues of premium rate regulation. ${ }^{46}$ During the recent hearings on consumer credit insurance held by the Senate Subcommittee on Antitrust and Monopoly, repeated inquiry was made as to the adequacy of the NAIC Model Bill to deal with the complex problem of rate regulation. .7 $^{4}$

Both the Model Bill and the UCCC approach the problem of rate regulation indirectly by requiring the premium charges to be reasonable in relation to the benefits provided. There is, however, a difference between the Model Bill and the UCCC with respect to the disapproval of forms by the insurance commissioner. The Model Bill states that

The Commissioner shall ... disapprove any such form if the benefits provided therein are not reasonable in relation to the premium charge, or if it contains provisions which are unjust, unfair, unequitable, misleading, deceptive or encourage misrepresentation of the coverage . . . .48

The corresponding provision in the UCCC reads as follows:

Within 30 days after the filing of any form or schedule [of premium rates or charges], he [the Commissioner] shall disapprove it if the premium rates or

\footnotetext{
"UCCC $\$ 4 . \mathrm{IrO}(\mathrm{I})$.

${ }^{40}$ See, e.g., Hearings Before the California Department of Insturance (April r967) [hereinafter cited as California Hearings); Hearings Before the Vermont Department of Banking and Instrance (April 1967) [hereinafter cited as Vermont Hearings]; Hearings Before the Wisconsin Department of Insurance (October I966).

${ }^{17}$ Hearings on the Consumer Credit Industry Before the Subcomm. on Antitrust and Monopoly of the Senate Comm. on the Judiciary, goth Cong., Ist Sess. (1967) [hereinafter cited as Hearings on the Constumer Credit Industry].

${ }^{18}$ Model BILI $\$ 7$ B.
} 
charges are unreasonable in relation to the benefits provided under the form, or if the form contains provisions which are unjust, unfair, inequitable, or deceptive, or encourage misrepresentation of the coverage . . . .49

The language in the UCCC reflects the drafters' intent to remove any doubt as to the insurance commissioner's authority to disapprove a premium rate as well as the power to disapprove a form. ${ }^{50}$ The former power is not explicitly granted in the Model Bill, but the lack of explicit power has not prevented premium rate regulation in a number of states.

Despite the inclusion of this authority in the UCCC, the problem of effective rate regulation will remain because the insurance commissioner still must decide what is "reasonable." A review of recent consumer credit insurance hearings reveals a dichotomy among insurers with respect to the regulation of premium rates for consumer credit insurance. ${ }^{51}$ The need for regulation is accepted, but there is no agreement as to how regulation may be fairly and effectively accomplished. Despite considerable effort to attain that objective, the issue remains unresolved.

The purpose of this section is to review the different positions on rate regulation. Because there has been only limited discussion of credit accident and health insurance premium rates, this section is restricted to the controversy in the regulation of credit life insurance premium rates.

The two principal propositions regarding rate regulation are $(a)$ the use of the fifty per cent loss ratio and $(b)$ the establishment of a maximum rate or schedule of rates. ${ }^{52}$ The essential distinction between the two regulatory approaches is that the first defines the maximum rate indirectly by requiring that the insurer's incurred losses amount to at least fifty per cent of the earned premium, while the second regulates directly through the establishment of a maximum premium rate. ${ }^{53}$ Both types of regulation apply to the premium rate charged the creditor by the insurer. This, in turn, is the rate the creditor may charge the debtor in states where either the Model Bill or the UCCC applies.

\section{A. Fifty Per Cent Loss Ratio}

As previously noted, the Model Bill authorizes the insurance commissioner to disapprove a company's policy forms if the benefits provided are not reasonable in relation to the premiums charged. The NAIC, in 1959, adopted a resolution which

\footnotetext{
${ }^{19}$ UCCC $\$ 4.203(2)$.

${ }^{50} \mathrm{UCCC} \$ 4.203$, Comment.

${ }^{81}$ See hearings cited supra note 46 .

52 The decremental scale is a variation of the maximum rate approach to premium rate regulation. With the decremental scale, the maximum premium rate which an insurer may charge a particular creditor is related inversely to the amount of insurance in force for that creditor. Thus, the largest creditors pay, and in turn charge, the lowest premium rate.

${ }^{88}$ The term "maximum rate" means the highest rate that may be charged unless an insurer presents evidence that a higher rate is justified and the insurance commissioner approves the "deviated" higher rate.
} 
recommended to all insurance commissioners "that a rate for Credit Life or Credit Accident and Health [insurance], producing a loss ratio of under $50 \%$ should be considered to be excessive." ${ }^{.54}$ In I966, the NAIC reaffirmed this position by adopting the so-called "Richmond Resolution," which called for the enforcement of section $\eta^{B}$ of the Model Bill by the use of the fifty per cent loss ratio and the promulgation of prima facie rates. ${ }^{55}$ The fifty per cent loss ratio has been understood to mean that incurred losses would equal at least fifty per cent of earned premiums. In concept, when an insurer has developed credible experience under the prima facie rate, the insurer's premium rate may be adjusted upward or downward if it does not produce a fifty per cent loss ratio-that is, does not result in the return of fifty per cent of premiums to the public in the form of benefits. If the prima facie rate produces a loss ratio in excess of fifty per cent, the insurer may file a request for a deviation to charge a higher rate. Conversely, if an insurer's loss ratio is less than fifty per cent, the insurance commissioner may order the insurer either to reduce the pemium rate or to increase benefits by an amount sufficient to produce a loss ratio of at least fifty per cent. The insurer is free, of course, to develop a loss ratio exceeding fifty per cent.

The major argument advanced in favor of the fifty per cent loss ratio is that it was recommended as a proper rate regulation technique by the NAIC after long and careful consideration. ${ }^{58}$ The proponents also believe that the fifty per cent loss ratio is simple to administer. To provide the necessary data for the enforcement of the fifty per cent loss ratio, the NAIC has recently adopted reporting forms for credit life and credit accident and health insurance. ${ }^{57}$ These forms are designed to give insurance departments information as to the type of coverages, the premium rates charged, and the loss experience of each insurer writing credit life and credit accident and health insurance.

Opponents of the fifty per cent loss ratio offer two principal objections: (a) the loss ratio is too low in comparison with other group insurance, thus permitting too much of the premium to be absorbed in administrative costs and creditor compensation, and $(b)$ its administration on a case-by-case basis is very burdensome. In testimony before the Senate Subcommittee on Antitrust and Monopoly, spokesmen for the Equitable Life Assurance Society of the United States and the Aetna Life Insurance Company indicated that their companies conduct group credit life insurance in much the same way as their other group insurance business. ${ }^{58}$ In the view of the Commissioner of Banking and Insurance of the State of Vermont, higher loss ratios should be developed in group consumer credit insurance since loss ratios in excess of fifty per cent are developed for other types of group insurance:

\footnotetext{
os I NAIC I96o ProceEdings 176.

${ }^{55} 2$ NAIC I 966 Procendings 402.

${ }^{50}$ Hearings on the Consumer Credit Industry, pt. 3, at 2444.

${ }^{67}$ I NAIC 1967 Proceedings $116 ; 2$ id. at 397.

${ }^{\mathrm{E}}$ Hearings on the Consumer Credit Industry, pt. 3, at $24 \mathrm{II}, 24 \mathrm{I} 8$.
} 
To a life insurance actuary, familiar with the efficiency of group life insurance, the suggestion that $50 \%$ is an appropriate loss ratio is upsetting. I know perfectly well that loss ratios can run as high as $80 \%$, perhaps $85 \%$, in credit insurance and still allow the creditor to receive a modest dividend and the insurer to make a profit. 59

Proponents of the fifty per cent loss ratio have denied that there is a substantial basis for comparing group consumer credit insurance to other forms of group insurance. For instance, the General Counsel of the Consumer Credit Insurance Association stated,

I am sure you are well aware of the fact that there are positive and significant differences [between employer-group life insurance and group credit life insurance]. Just to name a few, there is not a common industry such as is the case of group employer-employee; we don't have a common employer situation; there is no fluctuation of the rate by age; and there is no participation requirement. ${ }^{60}$

Insurance regulators have, on occasion, asked how the fifty per cent loss ratio should be enforced. Their question refers to the evidence that each group policy issued by an insurer produces a unique mortality cost. If each policy is to generate a loss ratio of at least fifty per cent, a premium rate must also be established on a case-by-case basis. If a department does not have the staff to enforce the fifty per cent loss ratio on that basis (or simply chooses not to do so), the prima facie rate becomes the rate at which most credit life insurance is written except when a higher rate can be justified by the insurer and a rate deviation is granted by the insurance department. The prima facie rate tends to become the minimum rate, as well as a maximum rate. ${ }^{61}$ From a practical standpoint, therefore, the establishment of a "reasonable" prima facie rate involves the same considerations as the establishment of any other "reasonable" maximum premium rate. Thus, the determination of a "reasonable" maximum rate is at the heart of the rate regulation controversy.

\section{B. Maximum Premium Rates}

As an alternative to the fifty per cent loss ratio, some insurance departments have promulgated a maximum rate or schedule of rates. If consumer credit insurance is written at these or lower rates, the insurer is presumed to be charging a reasonable premium rate.

The two principal views on the matter of establishing maximum premium rates (prima facie or otherwise) are presented by those who favor a maximum rate per hundred dollars of installment debt per year ${ }^{62}$ of sixty cents or less and those who

\footnotetext{
${ }^{50} I d .$, pt. I, at 66.

${ }^{\circ 0}$ Vermont Hearings 2.

${ }^{62}$ Hearings on the Consumer Credit Industry, pt. 3, at 2084, 2446; and California Hearings 83.

${ }^{62}$ All references to specific premium rates are in terms of cents per one hundred dollars of initial indebtedness repayable in twelve equal monthly installments. To simplify the reading, rates are expressed in terms of cents only.
} 
support higher maximum rates of seventy-five cents or more. Some proponents of the former view argue that on the basis of the claim cost of approximately thirty cents per one hundred dollars of initial indebtedness developed in the NAIC mortality studies, a fair rate for the "normal" case is sixty cents using the fifty per cent loss ratio as a benchmark. ${ }^{63}$ The logic of their advocacy of lower maximum premium rates is based on the following assumptions: (a) many insurers will charge the maximum rate allowed even if very low loss ratios are developed, and $(b)$ the insurer will request a rate deviation if abnormally high mortality expenses are developed. Based on these assumptions, they argue that the establishment of a maximum rate which will produce a reasonable loss ratio in the normal case is preferable to a higher rate, since the insurer will request a rate deviation when a higher-than-normal rate is justified.

Supporters of the higher maximum rate contend that the NAIC mortality studies do not demonstrate that an average claims cost of thirty cents is significant for the purposes of regulation. ${ }^{64}$ An insurer may experience higher claims costs as a result of (a) higher mortality experience of some groups and (b) provision of broader coverages. The latter point was emphasized by a spokesman for the American National Insurance Company during testimony before the Senate Subcommittee on Antitrust and Monopoly. He stated, "I think it is pure conjecture to discuss a particular rate unless we know what the company was offering for that particular rate." ${ }^{.5}$ These insurers state that as a result of higher mortality costs, they may be forced to seek rate deviations in order to operate profitably if low (sixty cents or less) maximum rates are promulgated. They argue, moreover, that they are sometimes required to exhibit an unusually high loss ratio before they are granted a rate deviation by the insurance department. ${ }^{66}$ They favor a higher maximum rate because it allows them to operate without the necessity of obtaining rate deviations.

\section{Conclusion}

The National Association of Insurance Commissioners, with the aid of responsible industry representatives, adopted a Model Bill which deals effectively with such problems in consumer credit insurance as sales of excessive amounts of insurance, pyramiding of coverages, lack of disclosure, overcharging, coercion, and nonpayment of claims. The Model Bill also authorizes the insurance commissioner to disapprove any policy form in which benefits are not reasonable in relation to premiums charged.

The proposed UCCC includes several sections regulating consumer credit in-

\footnotetext{
${ }^{03}$ Hearings on the Constmer Credit Industry, pt. $\mathrm{x}$, at 72-73.

o* Vermont Hearings 8; California Hearings 233.

ot Hearings on the Consumer Credit Industry, pt. 3, at 215I.

${ }^{\circ}$ Vermont Hearings 7 ; California Hearings 247-48.
} 
surance that complement some of the provisions of the NAIC Model Bill. In contrast to the Model Bill, which provided a mechanism only for regulating insurers, the UCCC is concerned with the conduct of creditors in transactions involving consumer credit insurance. Thus, the UCCC affords additional safeguards for the consumer, both through specific remedies made available to him and through an enforcement mechanism set up to police creditors in his interest.

With regard to charges for consumer credit insurance, both the NAIC Model Bill and the UCCC provide controls over premium rates indirectly by requiring reasonable benefits for insured debtors in relation to premium charges. However, the Model Bill and the UCCC do not specify any standard or approach in determining a reasonable benefit-cost ratio, and the implementation of the reasonable benefits language is left to the discretion of the insurance commissioner. The NAIC, in 1959 and again in the so-called "Richmond Resolution," adopted in I966, recommended to insurance commissioners the fifty per cent loss ratio for rate supervision, but the appropriateness of this standard is open to debate. Thus, the determination of reasonable premium rates remains the most pressing problem in the field of consumer credit insurance. 